\title{
The quality of environmental impact reports for projects with the potential of affecting wetlands in South Africa
}

\author{
LA Sandham*, MJ Moloto and FP Retief \\ Environmental Assessment Research Group, School of Environmental Sciences, North West University, Private Bag X6001, \\ Potchefstroom 2520, South Africa
}

\begin{abstract}
In South Africa certain development activities, which may have a substantial detrimental effect on the environment, require an environmental impact assessment (EIA), including projects with the potential of affecting wetlands. A key element of the EIA process is the submission of an environmental impact report (EIR) for review in order to determine whether the report is adequate and/or whether a greater quantity of information is required before the project can be authorised. The information available to decision-makers in the EIR is a major determinant in the outcome of wetland protection and/or destruction.

The quality of 4 environmental impact reports of large projects with the potential of impacting on wetlands was assessed using an EIA report quality review checklist. It is concluded that the quality of the 4 reports was generally satisfactory but certain areas were found to be poorly performed, i.e. identification and evaluation of impacts to the potential detriment of the wetlands for which the EIAs were performed

To improve the quality of the reports for projects with the potential of affecting wetlands it is recommended that a quality review checklist be used by EIA practitioners and authorities as an additional tool to the EIA regulations and the integrated environmental management series. This should assist in ensuring that key aspects are addressed before submission to the relevant authority, and will also contribute to establishing a baseline of EIR quality for evaluation of wetlands EIA practice under the new regulations promulgated in 2006.
\end{abstract}

Keywords: environmental impact report (EIR), environmental impact assessment, quality review, wetlands

\section{Introduction}

Wetlands have been referred to as 'kidneys of the landscape', because of the functions they perform in the hydrological and chemical cycles (e.g. groundwater replenishment, water purification, sediment and nutrient retention, flood control), and as 'biological supermarkets' because of the extensive food webs and rich biodiversity they support (Odum, 1983; Bardecki, 1984; Barbier et al., 1996; Kotze, 2000; Silvius et al., 2000; Furter, 2003). There are different definitions of wetlands depending on the user or interest groups. The Ramsar Convention of which South Africa is a member party, defines wetlands in Article 1.1 of the Convention Text as 'areas of marsh, fen, peatland or water, whether natural or artificial, permanent or temporary, with water that is static or flowing, fresh, brackish or salt, including areas of marine water the depth of which at low tides does not exceed six metres.' (Ramsar Convention, 1994). This definition of wetlands recognises the often dynamic nature of wetlands, and allows the consideration of the place that they have within the broader context of the landscape. However, despite the benefits they offer, wetlands are amongst the most threatened ecosystems in the world. These threats, resulting in wetland losses and associated declines in biodiversity and ecosystem function, include pollution, waste disposal, mining, groundwater abstraction, agriculture, urbanisation, deficiency in planning, policy deficiencies and institutional weakness (Dugan, 1994; Barbier et al., 1996).

Internationally, EIA is one of the most successful and widely adopted environmental policy implementation instruments that

* To whom all correspondence should be addressed.

+27 18 299-1585; fax: +27 18 299-1580;

e-mail: luke.sandham@nwu.ac.za

Received 16 October 2007; accepted in revised form 19 February 2008 has emerged over the past 3 decades. EIA is an instrument to identify and evaluate the potential environmental consequences of a proposed development action in order to support decisionmaking and sound environmental management (Glasson et al., 1995; Sadler, 1996; Wood, 1988; Wood, 2003). Clearly, priceless ecosystems such as wetlands are susceptible to significant adverse impacts resulting from developments. In an effort to protect wetlands, Canada and the World Bank have developed and use a guideline document to provide guidance to EIA practitioners in the use of EIA, specifically for projects likely to affect biodiversity and wetlands (Canadian Environmental Assessment Agency, 1996; The World Bank, 1997; 2002). Similarly, guideline documents have been developed for parties to the Ramsar Convention to include wetlands and biodiversity-related issues into EIA legislation and/or processes (Ramsar Convention, 2007). The guideline documents assist EIA practitioners to highlight potential impacts likely to be generated and to indicate the type and scope of assessment and environmental planning and management.

This article presents the research results of the first empirical study exploring the quality of EIA reports for projects that have the potential to affect wetlands in South Africa. It starts by briefly introducing wetlands in the South African EIA context and a discussion of the problem statement and the research methodology. This is followed by the research results and analysis. The article ends with conclusions and recommendations towards improving the quality of EIA reports for projects affecting wetlands.

\section{The South African context}

It has been estimated that in South Africa more than $50 \%$ of the wetlands ecosystems have been lost mainly through agricul- 
tural development and poor land management (Walmsley, 1988; DEAT, 1999). This is a drastic impact on a precious resource in a water-scarce country, and requires every effort and hence optimal use of appropriate environmental management tools to ensure maximum compliance with the legal as well as the Ramsar requirements.

Voluntary EIAs have been conducted in South Africa since the early 1970s (Sowman et al., 1995), but only became mandatory in September 1997 upon promulgation of regulations in terms of the Environment Conservation Act, No 73 of 1989 (South Africa, 1989; 1997). These regulations established compulsory EIA practice in South Africa, and were replaced in July 2006 by new regulations promulgated in terms of Section 24(5) of the National Environmental Management Act (NEMA), No 107 of 1998 (South Africa, 1998; 2006).

In terms of both sets of regulations, wetlands are a listed activity requiring an EIA for projects likely to affect wetlands. In the 1997 regulations (R1182) activities with the potential to affect wetlands are either explicitly indicated (S7) or implied (S1 (i, j, k, 1, n)). In the 2006 regulations, similar references are made for basic assessments (Regulation 386: S1 (m, n,) S4, S11, S13, S20 and S23), as well as for scoping and environmental impact assessment (thorough assessments) (Regulation 387: S4, S6) (South Africa, 2006).

Since the new regulations have been in force for a short period, this article focuses on EIA practice in the first era of mandatory EIA (September 1997 - June 2006). These results provide a valuable base line of EIR quality to evaluate future trends in performance.

\section{Problem statement}

The EIA process requires that an independent consultant be appointed by the developer to conduct the EIA and to submit an environmental impact report (EIR) to the relevant competent authority. This submission is preceded by a comprehensive and transparent consultation and participation process, involving a wide range of stakeholders (DEAT, 1998). This phase could involve the generation and scrutiny of a number of draft versions of the EIR prior to submission. However, the record of decision is issued on the basis of the information provided in the final EIR, and it can therefore be regarded as the principal basis for decision making by the relevant environmental authorities. The latter is supported by recent South African EIA case law, such as the case of Eskom vs. Earth Life Africa regarding the EIA decision on the proposed prototype of a pebble bed modular nuclear reactor. It is therefore evident that sound environmental decision making relies heavily on the quality of the contents of the EIR. In the case of wetland projects, the quality of the EIR therefore exerts a large influence on the extent of wetland protection and/or destruction, hence also on South Africa's commitment to Ramsar.
It comes therefore as no surprise that EIR quality review is widely considered to be an essential component of a wellfunctioning EIA system. Internationally a number of studies have been published relating to EIR quality review (Ross, 1987; Elkin and Smith, 1988; Lee and Colley, 1992; Lee and Brown, 1992; Geraghty, 1996; Leu et al., 1996; Hickie and Wade, 1998; Lee, 2000; Weston, 2000; Simpson, 2001). The approach of these review methodologies is largely the same, consisting of a hierarchical grouped set of criteria focusing on aspects of the generic EIA process. In South Africa, however, limited research has been conducted in this field. The main focus thus far has been on the development of a generic quality review package for EIR based on the Lee-Colley quality review package (Lee and Colley, 1992; Lee et al., 1999; Sandham and Pretorius, 2007). Moreover, no international or locally published studies could be found on the quality of EIR specifically for projects with the potential of impacting on wetlands.

In order to address this hiatus, the objective of the research was to determine the quality of selected environmental impact reports, with a view to providing a base line of EIR quality for projects related to wetlands. The results presented here also highlight areas for potential improvement in EIR quality.

\section{EIR report review methodology}

Probably the most well-known and widely applied EIR quality review package in developed and developing countries (Ibrahim, 1992; Rout, 1994; Mwalyosi and Hughes, 1998), is the Lee and Colley package, originally designed with particular reference to EIA applications in the UK (Lee and Colley, 1992; Lee and Brown, 1992; Lee and Dancey, 1993; Barker and Wood, 1999; Lee et al., 1999; Lee, 2000). Based on the Lee and Colley package, a generic EIR quality review package has already been developed for South Africa (Sandham and Pretorius, 2007). It is, however, recognised that this generic package needs to be adapted to review EIR quality in specific sectors such as water management, and more specifically, wetlands. Therefore, amendments were made for the purpose of this study at the subcategory level to include specific wetlands issues. These issues were based on the wetland aspects highlighted by the Canadian Environmental Assessment Agency (1996), the World Bank (1997; 2002) and the Ramsar Convention (2007).

\section{Structure of the review package}

The review package consists of multiple criteria arranged in a 4-level hierarchical structure consisting of an overall report grade, review areas, categories and sub-categories, which are used to assess the quality of the environmental impact reports (Fig. 1). The review topics are grouped hierarchically from 81 sub-categories through 15 review categories and 4 review areas

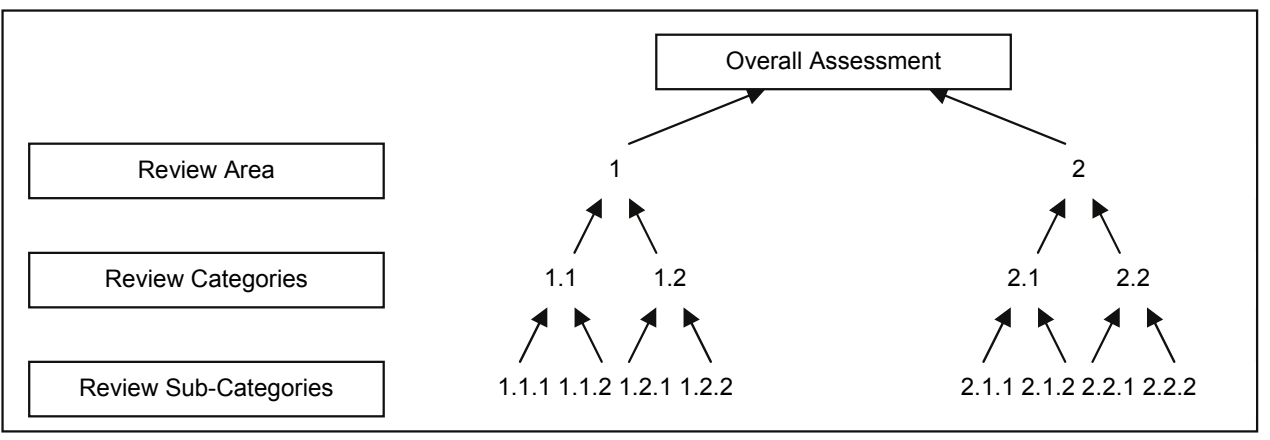

Figure 1

Hierarchical structure of the Lee and Colley (1992) EIR review package. Level 4 - Overall assessment of EIR; Level 3 - Assessment of review areas; Level 2 Assessment of review categories; Level 1 Assessment of review sub-categories. 


\begin{tabular}{|l|l|}
\hline \multicolumn{2}{|c|}{ List of assessment symbols (adapted from Lee et al., 1999) } \\
\hline Symbol & Explanation \\
\hline A & Generally well performed, no important tasks left incomplete \\
\hline B & Generally satisfactory and complete, only minor omissions and inadequacies \\
\hline C & Can be considered just satisfactory despite omissions and/or inadequacies \\
\hline D & Parts are well attempted but must, as a whole, be considered just unsatisfactory because of omissions or inadequacies \\
\hline E & Not satisfactory, significant omissions or inadequacies \\
\hline F & Not satisfactory, important task(s) poorly done or not attempted \\
\hline N/A & Not applicable. The review topic is not applicable or irrelevant in the context of this EIA report \\
\hline
\end{tabular}

to a single overall score / grade. This checklist will be referred to as the (South African) wetlands review package (SAWRP).

The quality review involves evaluating how well a number of assessment tasks (sub-categories, categories and areas) have been performed. The reviewer commences the review at the lowest level (sub-categories), which contains simple criteria relating to specific tasks and procedures. Then drawing upon these assessments, he/she moves upwards progressively from one level to another, applying more complex criteria to broader tasks and procedures in the process until the overall assessment of the environmental impact report has been completed. The assessment from applying each criterion is recorded by the reviewer on a collation sheet, using a standard list of assessment symbols (Table 1). Letters of the alphabet are used as symbols rather than numerals to discourage reviewers from crude arithmetic aggregation to obtain assessments at the higher levels in the assessment hierarchy. The symbols $\mathrm{A}$ to $\mathrm{C}$ represent generally satisfactory performance (A: very satisfactory, B: satisfactory and $\mathrm{C}$ : just satisfactory) and $\mathrm{D}$ to $\mathrm{F}$ generally unsatisfactory performance at each of the levels in the review hierarchy.

\section{Selection and description of case studies}

Case study research has become widely accepted as a valid approach to quality review (Eisenhardt, 2002; Robson, 2002). The main challenges presented by this approach relate firstly to selection of suitable cases and secondly to appropriate generalisation of results. Conclusions reached should demonstrate external validity by avoiding broad generalisations as in a statistical survey approach. Rather, the research follows a so-called 'replication logic' (Yin, 2003) which argues that results could be expected to replicate under similar conditions within the South African context.

For the purposes of this research 4 cases were selected. Their selection is justified on the basis of their being the only available EIRs for large projects with the potential of impacting on wetlands requiring full EIA (at national level), at the time that the research was conducted. The selected case studies can be summarised as follows (the names in brackets will be used to refer to the case studies):

- The Braamhoek Pump Storage Scheme (Braamhoek) is situated $23 \mathrm{~km}$ north-east of Van Reenen on the boundary of the KwaZulu-Natal and the Free State Provinces. The development involved the construction of a hydro-electric pump storage scheme including two reservoirs (upper and lower). The wetlands on the proposed upper reservoir site will be inundated and therefore permanently lost. Furthermore, the wetlands downstream of the reservoir will also be impacted.

- The Mooi-Mgeni River Transfer Scheme - receiving streams (Mooi-Mgeni). The proposed development involved pumping water from the Mearns Weir in the Mooi River (near the town of Mooi River, KwaZulu-Natal) across the water divide into the Mpofana, Lions and Mgeni receiving streams in the catchment of the Midmar Dam, to augment the water supply to Durban and Pietermaritzburg. The proposed development is likely to impact the riparian vegetation and wetlands along the receiving streams.

- Mooi-Mgeni Transfer Scheme - raising of the Midmar Dam wall (Midmar Dam). The Midmar Dam is situated near the town of Howick in the midlands of KwaZulu-Natal, and the proposed development involved the raising of the dam wall by $3.5 \mathrm{~m}$ in order to improve the available water supply from the Midmar Dam. Raising the dam wall is likely to impact on wetlands on the southern side of the Midmar Dam by inundation.

- The development of infrastructure in the Seekoeivlei Nature Reserve (Seekoeivlei). The proposed development comprised of the construction of cottages, a caravan park, information and conference centre within the Seekoeivlei Nature Reserve, which is a Ramsar -designated wetland, located near the town of Memel in the Free State.

The EIRs of these projects were reviewed using the wetlands review package (SAWRP).

\section{Quality review process}

Two reviewers independently conducted the review of the environmental impact reports for Braamhoek, Mooi-Mgeni, Midmar Dam and Seekoeivlei. The reviewers met after the completion of their separate reviews to compare their results. Differences in results between the reviewers were identified, re-examined, discussed and consensus reached. It was found that while there were frequent differences in scores at the sub-category and category levels, there is a substantial level of similarity in the results obtained by different reviewers of the same EIR at the higher level in the pyramid, i.e. review area and overall report score. Only consensus scores are presented here (Tables 2 and 3).

\section{Results}

While the assessment symbols A - well performed, B - satisfactory and complete, and $\mathrm{C}$ - just satisfactory, all reflect differing degrees of 'satisfactoriness', only A and B scores can be regarded as well done, and similarly, E and F scores can be regarded as poorly done. Therefore, in order to determine strengths and weaknesses, the best (A to B) and worst (E to F) grades are discussed.

\section{Overall quality of the EIR sample}

The 4 reports were rated satisfactory despite omissions and/ or inadequacies with a B score (satisfactory) for Braamhoek, 
TABLE 2

Review results at the review category, review area and report levels

\begin{tabular}{|c|c|c|c|c|}
\hline Overall EIR score, review areas and review categories & $\begin{array}{c}\text { Braam- } \\
\text { hoek }\end{array}$ & $\begin{array}{l}\text { Mooi- } \\
\text { Mgeni }\end{array}$ & $\begin{array}{c}\text { Midmar } \\
\text { Dam }\end{array}$ & \begin{tabular}{|c|}
$\begin{array}{c}\text { Seekoei- } \\
\text { vlei }\end{array}$ \\
\end{tabular} \\
\hline Overall EIR scores & $\mathrm{B}$ & $\mathrm{B}$ & $\mathrm{C}$ & $\mathrm{B}$ \\
\hline Review Area 1. Description of the development, local environment and base line studies & $\mathrm{B}$ & $\mathrm{B}$ & $\mathrm{B}$ & $\mathrm{B}$ \\
\hline 1.1. Description of the development & $\mathrm{C}$ & $\mathrm{B}$ & $\mathrm{B}$ & $\mathrm{B}$ \\
\hline 1.2. Site description & $\mathrm{C}$ & E & $\mathrm{C}$ & $\mathrm{B}$ \\
\hline 1.3. Wastes & $\mathrm{B}$ & $\mathrm{F}$ & $\mathrm{C}$ & $\mathrm{B}$ \\
\hline 1.4. Environment description & $\mathrm{B}$ & $\mathrm{A}$ & $\mathrm{A}$ & $\mathrm{B}$ \\
\hline 1.5. Baseline conditions & $\mathrm{C}$ & $\mathrm{B}$ & $\mathrm{B}$ & $\mathrm{B}$ \\
\hline Review Area 2. Identification and evaluation of impacts & $\mathrm{B}$ & $\mathrm{C}$ & $\mathrm{B}$ & $\mathrm{C}$ \\
\hline 2.1. Definition of potential impacts & $\mathrm{C}$ & $\mathrm{B}$ & $\mathrm{B}$ & $\mathrm{C}$ \\
\hline 2.2. Identification of impacts & $\mathrm{C}$ & $\mathrm{F}$ & $\mathrm{D}$ & $\mathrm{D}$ \\
\hline 2.3. Scoping & $\mathrm{B}$ & $\mathrm{C}$ & $\mathrm{B}$ & $\mathrm{C}$ \\
\hline 2.4. Prediction of impact magnitude & $\mathrm{B}$ & $\mathrm{C}$ & $\mathrm{B}$ & $\mathrm{C}$ \\
\hline 2.5. Assessment of impact significance & $\mathrm{B}$ & $\mathrm{C}$ & $\mathrm{C}$ & $\mathrm{C}$ \\
\hline Review Area 3. Alternatives and mitigation of impacts & $\mathrm{B}$ & $\mathrm{B}$ & $\mathrm{C}$ & $\mathrm{B}$ \\
\hline 3.1. Alternatives & $\mathrm{C}$ & $\mathrm{N} / \mathrm{A}$ & $\mathrm{C}$ & $\mathrm{B}$ \\
\hline 3.2. Scope and effectiveness of mitigation measures & $\mathrm{B}$ & $\mathrm{C}$ & $\mathrm{C}$ & $\mathrm{B}$ \\
\hline Review Area 4. Communication of results & $\mathrm{B}$ & $\mathrm{A}$ & $\mathrm{B}$ & $\mathrm{B}$ \\
\hline 4.1. Layout (information) & $\mathrm{D}$ & A & $\mathrm{B}$ & B \\
\hline 4.2. Presentation (information) & $\mathrm{B}$ & $\mathrm{B}$ & $\mathrm{B}$ & $\mathrm{B}$ \\
\hline 4.3. Emphasis (impacts) & $\mathrm{C}$ & $\mathrm{B}$ & B & B \\
\hline
\end{tabular}

Mooi-Mgeni and Seekoeivlei and a C score (just satisfactory) for Midmar (Table 2 - top row). These findings are very similar to those reported by Lee (2000) for EIRs in general in both highincome and low-income countries, where $70 \%$ or more of EIRs were graded at $\mathrm{C}$ or above. That all four reports were considered satisfactory (3B) and just satisfactory (1C) in terms of the review results, suggests that the decision made by the environmental authority was based on overall satisfactory quality information. However, it is important to further investigate the quality of information reflected by the different components of the EIR. This is achieved by focusing on the results for the lower tiers of the review process, grouped by review areas.

\section{Quality of the review areas}

It was found in the assessment that all 4 review areas were performed satisfactorily (Table 2). However, Review Area 1 (Description of the development and the environment)) and Review Area 4 (Communication of results) can be regarded as well done, with 4Bs and 1A 3Bs respectively, whereas Review Area 3 (Alternatives and mitigation of impacts)) and Review Area 2 (Identification and evaluation of key impacts) were weaker with respectively $3 \mathrm{Bs} 1 \mathrm{C}$ and $2 \mathrm{Bs} 2 \mathrm{Cs}$. As with the overall reports, these are in agreement with international findings (Lee, 2000) and elsewhere in South Africa (Sandham and Pretorius, 2007), where better performance is observed in the more descriptive areas (Review Areas 1 and 4), and poorer performance in the technically more demanding areas (Review Areas 2 and 3).

\section{Review Area 1 - Description of the development and the environment}

With the exception of the cumulative impacts, the EIRs contained satisfactory descriptions of the environment (2 As and 2 Bs / B A A B), of the development and of the base line conditions (both $3 \mathrm{Bs}$ and $1 \mathrm{C}$ ). However, poorer performances were observed regarding the site description (1 E) and waste (1 F). Particular problem areas related to the estimated duration of the different phases, number of workers entering the site and their access to the site, likely means of transport, and infrastructure required, which in most of the EIRs were either poorly or not even attempted. Information on the means of transporting raw materials and products to and from the site and the approximate quantities involved, as well as estimated quantities and disposal of waste were generally also less than satisfactory, as were the replacement costs of goods produced by the wetlands, and an outline of the assessment methods used for determining the wetland functions, values and uses.

\section{Review Area 2 - Identification and evaluation of key impacts}

In this review area, 2 reports received a satisfactory grading and 2 reports were found to be just satisfactory, making this the least well-performed review area.

Definition of impacts, scoping, prediction of impact magnitude and assessment of significance were all dealt with to a satisfactory degree (Bs and Cs), although in many cases the impacts were identified for the project as a whole, even though the regulations require that the impacts of each phase of the development (planning, construction, operation and decommissioning) be identified separately. Scoping (particularly in the South African EIA system) comprises a vital part of the EIA process, and the analysis revealed that the process is done fairly well, with all of the reports being rated as satisfactory in this category. A somewhat poorer performance was observed for the identification of impacts, where only one project was rated as just satisfactory (Braamhoek) and the others were rated $\mathrm{F}$ and $\mathrm{D}$ (Table 2).

Omissions and deficiencies observed in this area included: Limited details of scoping methods are provided, and coverage is mainly confined to direct impacts with poor treatment of cumulative and secondary impacts. Assessment of impacts 


\begin{tabular}{|c|c|c|c|c|c|c|c|c|c|c|c|}
\hline & Sub-category quality $r$ & & & & & $\begin{array}{l}E 3 \\
\text { to }\end{array}$ & parate sub-categories per ca & & & & \\
\hline 竎 & CRITERIA DESCRIPTION* & 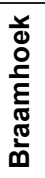 & 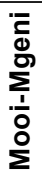 & $\begin{array}{l}\frac{\grave{\Sigma}}{\sqrt{0}} \\
\frac{\mathbf{E}}{0} \\
\frac{0}{\Sigma}\end{array}$ & 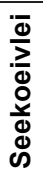 & $\frac{3}{\frac{3}{0}} \frac{0}{0}$ & CRITERIA DESCRIPTION & 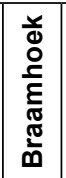 & 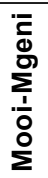 & 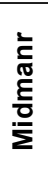 & 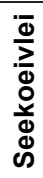 \\
\hline 1.1.1. & Identification of applicant & $\mathrm{A}$ & $\mathrm{B}$ & $\mathrm{A}$ & $\mathrm{B}$ & 2.1 .1 & $\begin{array}{l}\text { Assessment of significant potential } \\
\text { impacts }\end{array}$ & A & $\mathrm{B}$ & $\mathrm{B}$ & $\mathrm{B}$ \\
\hline 1.1.2. & $\begin{array}{l}\text { Purpose and objectives of devel- } \\
\text { opment }\end{array}$ & $\mathrm{A}$ & $\mathrm{A}$ & $\mathrm{A}$ & $\mathrm{B}$ & 2.1 .2 & Non-standard operating conditions, & $\mathrm{F}$ & $\mathrm{B}$ & $\mathrm{B}$ & $\mathrm{C}$ \\
\hline 1.1 .3 & $\begin{array}{l}\text { Description and nature of activity/ } \\
\text { development }\end{array}$ & $\mathrm{A}$ & $\mathrm{A}$ & $\mathrm{A}$ & $\mathrm{B}$ & 2.1 .3 & Deviation from baseline & $\mathrm{B}$ & $\mathrm{B}$ & $\mathrm{B}$ & $\mathrm{E}$ \\
\hline 1.1 .4 & Description of the site & $\mathrm{B}$ & $\mathrm{C}$ & $\mathrm{B}$ & $\mathrm{B}$ & 2.1 .4 & Beneficial impacts & $\mathrm{C}$ & $\mathrm{A}$ & $\mathrm{B}$ & $\mathrm{C}$ \\
\hline 1.1 .5 & Proposed location & $\mathrm{C}$ & $\mathrm{A}$ & $\mathrm{B}$ & $\mathrm{B}$ & 2.1 .5 & Indirect effects, & $\mathrm{D}$ & $\mathrm{B}$ & $\mathrm{B}$ & B \\
\hline 1.1.6. & $\begin{array}{l}\text { Description of processes and } \\
\text { technology employed }\end{array}$ & $\mathrm{C}$ & $\mathrm{N}$ & $\mathrm{C}$ & $\mathrm{N}$ & 2.1 .6 & Cumulative \& secondary impacts & $\mathrm{E}$ & $\mathrm{D}$ & $\mathrm{D}$ & $\mathrm{F}$ \\
\hline 1.1 .7 & Expected rate of production & $\mathrm{A}$ & $\mathrm{A}$ & $\mathrm{N}$ & $\mathrm{N}$ & 2.1 .7 & Stakeholders engagement & $\bar{A}$ & $\mathrm{C}$ & $\mathrm{B}$ & $\mathrm{F}$ \\
\hline 1.1 .8 & $\begin{array}{l}\text { Raw materials used during differ- } \\
\text { ent phases }\end{array}$ & $\mathrm{E}$ & $\mathrm{N}$ & $\mathrm{F}$ & $\mathrm{D}$ & 2.1 .8 & $\begin{array}{l}\text { Agreement between consultant and spe- } \\
\text { cialist report(s) }\end{array}$ & $\mathrm{C}$ & $\mathrm{B}$ & $\mathrm{C}$ & $\mathrm{F}$ \\
\hline 1.1 .9 & Availability water \& materials & $\mathrm{D}$ & $\mathrm{B}$ & $\mathrm{F}$ & $\mathrm{C}$ & 2.2 .1 & Assess Impacts in all phases & $\mathrm{C}$ & $\mathrm{F}$ & $\mathrm{E}$ & $\mathrm{D}$ \\
\hline 1.2 .1 & Site plan & $\mathrm{B}$ & $\mathrm{N}$ & $\mathrm{B}$ & $\mathrm{B}$ & 2.2 .2 & All possible impacts identified & $\mathrm{C}$ & $\mathrm{F}$ & $\mathrm{D}$ & $\mathrm{D}$ \\
\hline 1.2 .2 & Description land use & $\mathrm{D}$ & $\mathrm{N}$ & $\mathrm{B}$ & $\mathrm{B}$ & 2.3 .1 & Example of notice in media & $\bar{C}$ & $\mathrm{~B}$ & $\mathrm{E}$ & $\mathrm{B}$ \\
\hline 1.2 .3 & Duration of phases & $\mathrm{E}$ & $\mathrm{F}$ & $\mathrm{F}$ & $\mathrm{B}$ & 2.3 .2 & Onsite Notice & $\mathrm{N} / \mathrm{A}$ & $\mathrm{E}$ & $\mathrm{F}$ & $\mathrm{C}$ \\
\hline 1.2 .4 & Expected workers and visitors & $\mathrm{B}$ & $\mathrm{F}$ & $\mathrm{F}$ & $\mathrm{F}$ & 2.3 .3 & Identify affected people & A & $\mathrm{B}$ & $\mathrm{C}$ & $\mathrm{C}$ \\
\hline 1.2 .5 & Access to site and transport & $\mathrm{C}$ & $\mathrm{F}$ & $\mathrm{F}$ & $\mathrm{B}$ & 2.3 .4 & Identify interested people & $\mathrm{C}$ & $\mathrm{B}$ & $\mathrm{A}$ & $\mathrm{C}$ \\
\hline 1.2 .6 & Infrastructure required to & $\mathrm{D}$ & $\mathrm{F}$ & $\mathrm{F}$ & $\mathrm{B}$ & 2.3 .5 & Procedures for participation & $\bar{A}$ & $\mathrm{~B}$ & $\mathrm{~A}$ & $\mathrm{C}$ \\
\hline 1.3 .1 & Quantities \& disposal routes & $\mathrm{A}$ & $\mathrm{F}$ & $\mathrm{C}$ & $\mathrm{B}$ & 2.3 .6 & Provision for I\&AP views & B & $\mathrm{B}$ & A & $\mathrm{C}$ \\
\hline 1.3 .2 & Disposal \& handling & $\mathrm{C}$ & $\mathrm{F}$ & $\mathrm{D}$ & $\mathrm{B}$ & 2.3.7. & List of issues identified & A & $\mathrm{B}$ & $\mathrm{A}$ & $\mathrm{B}$ \\
\hline 1.4.1. & Likely area to affected & $\mathrm{A}$ & $\mathrm{A}$ & $\mathrm{B}$ & $\mathrm{B}$ & 2.3 .8 & Notification criteria for participation & $\mathrm{B}$ & $\mathrm{D}$ & $\mathrm{E}$ & $\mathrm{F}$ \\
\hline 1.4 .2 . & Biophysical description of site & $\mathrm{A}$ & $\mathrm{A}$ & $\mathrm{A}$ & $\mathrm{B}$ & 2.3 .9 & All the views as addendum & $\mathrm{B}$ & $\mathrm{D}$ & $\mathrm{E}$ & $\mathrm{B}$ \\
\hline 1.4 .3 . & Biological processes & A & A & A & A & 2.3 .10 & Key impacts for further study & $\bar{A}$ & $\mathrm{~A}$ & $\mathrm{~A}$ & $\mathrm{~B}$ \\
\hline 1.4 .4 & Social characteristics & $\mathrm{A}$ & A & $\mathrm{B}$ & A & 2.4 .1 & Prediction of impact magnitude & A & $\mathrm{C}$ & $\mathrm{C}$ & $\mathrm{B}$ \\
\hline 1.4 .5 . & Current cumulative impacts & $\mathrm{E}$ & $\mathrm{E}$ & $\mathrm{C}$ & $\mathrm{F}$ & 2.4 .2 & Express predictions of impact in & $\mathrm{C}$ & $\mathrm{C}$ & $\mathrm{C}$ & $\mathrm{F}$ \\
\hline 1.4 .6 & $\begin{array}{l}\text { Location in hydro-geographical } \\
\text { basin }\end{array}$ & $\mathrm{A}$ & $\mathrm{A}$ & $\mathrm{B}$ & $\mathrm{B}$ & 2.5 .1 & Impact on community & $\mathrm{B}$ & $\mathrm{B}$ & $\mathrm{B}$ & $\mathrm{B}$ \\
\hline 1.4 .7$. & Water and wetland issues & A & A & A & $\mathrm{B}$ & 2.5 .2 & Significance: duration, intensity, etc & B & $\mathrm{E}$ & $\mathrm{C}$ & $\mathrm{B}$ \\
\hline 1.4 .8 . & Consider Ramsar attributes & $\mathrm{N}$ & $\mathrm{N}$ & $\mathrm{N}$ & $\mathrm{B}$ & 2.5 .3 & Method: ranking significance & A & $\mathrm{E}$ & $\mathrm{B}$ & $\mathrm{F}$ \\
\hline 1.5.1. & $\begin{array}{l}\text { Important components of the } \\
\text { affected environment }\end{array}$ & $\mathrm{A}$ & $\mathrm{A}$ & $\mathrm{B}$ & $\mathrm{B}$ & 2.5 .4 & Uncertainties \& lack of data & $\mathrm{D}$ & $\mathrm{B}$ & $\mathrm{C}$ & $\mathrm{E}$ \\
\hline 1.5.2. & $\begin{array}{l}\text { Interaction \& effect of project on } \\
\text { environment }\end{array}$ & A & $\mathrm{B}$ & $\mathrm{C}$ & $\mathrm{B}$ & 3.1.1. & Methods to identify alternatives & B & $\mathrm{N}$ & $\mathrm{C}$ & $\mathrm{E}$ \\
\hline 1.5 .3 & Wetland specialist & $\mathrm{A}$ & $\mathrm{A}$ & $\mathrm{B}$ & $\mathrm{B}$ & 3.1 .2 & Description of range of alternatives & $\bar{C}$ & $\mathrm{~N}$ & $\mathrm{C}$ & $\mathrm{B}$ \\
\hline 1.5 .4 & Socio-economic benefits & $\mathrm{C}$ & $\mathrm{D}$ & $\mathrm{C}$ & $\mathrm{D}$ & 3.1 .3 & Minimum of two (2) alternatives & F & $\mathrm{N}$ & $\mathrm{C}$ & $\mathrm{B}$ \\
\hline 1.5 .5 . & $\begin{array}{l}\text { Replacement costs of goods pro- } \\
\text { duced by the wetland }\end{array}$ & $\mathrm{F}$ & $\mathrm{N}$ & $\mathrm{C}$ & $\mathrm{F}$ & 3.1 .4 & Discussion and reasons for final choice & $\bar{C}$ & $\mathrm{~N}$ & $\mathrm{C}$ & $\mathrm{B}$ \\
\hline 1.5.6. & Data on wetland variations & A & $\mathrm{C}$ & $\mathrm{D}$ & $\mathrm{B}$ & 3.2 .1 & Mitigation measures considered & B & A & $\mathrm{B}$ & $\mathrm{B}$ \\
\hline 1.5 .7 & $\begin{array}{l}\text { Current and potential wetland } \\
\text { functions, values and uses }\end{array}$ & $\mathrm{C}$ & $\mathrm{C}$ & $\mathrm{C}$ & $\mathrm{C}$ & 3.2 .2$. & Mitigation include alternatives & $\mathrm{C}$ & $\mathrm{A}$ & $\mathrm{B}$ & $\mathrm{B}$ \\
\hline 1.5 .8 & Benefits to society & $\mathrm{C}$ & $\mathrm{C}$ & $\mathrm{C}$ & $\mathrm{B}$ & 3.2 .3 & Mitigation measures clearly defined & $\mathrm{B}$ & $\mathrm{A}$ & $\mathrm{C}$ & $\mathrm{B}$ \\
\hline 1.5 .9 & $\begin{array}{l}\text { Ecosystem / catchments bounda- } \\
\text { ries for EIA }\end{array}$ & $\mathrm{B}$ & $\mathrm{B}$ & $\mathrm{B}$ & $\mathrm{F}$ & 3.2.4. & Effectiveness of mitigation & B & A & $\mathrm{C}$ & $\mathrm{B}$ \\
\hline 1.5 .10 & Wetlands in area described. & $\mathrm{A}$ & $\mathrm{B}$ & $\mathrm{A}$ & $\mathrm{B}$ & 4.1 .1 & Introduction to project \& aim of EIA & B & $\mathrm{A}$ & $\mathrm{B}$ & $\mathrm{A}$ \\
\hline 1.5 .11 & National wetland inventory & $\mathrm{B}$ & $\mathrm{N}$ & $\mathrm{N}$ & $\mathrm{N}$ & 4.1 .2$. & Information logically arranged & $\mathrm{D}$ & $\mathrm{A}$ & $\mathrm{B}$ & $\mathrm{B}$ \\
\hline 1.5 .12 & Ramsar status verified & $\mathrm{A}$ & $\mathrm{N}$ & $\mathrm{N}$ & $\mathrm{B}$ & 4.1 .3 & External sources acknowledged & $\mathrm{C}$ & A & $\mathrm{B}$ & $\mathrm{C}$ \\
\hline 1.5 .13 & National wetland policy & $\mathrm{N}$ & $\mathrm{N}$ & $\mathrm{N}$ & $\mathrm{N}$ & 4.2.1. & Presentation of information & $\mathrm{B}$ & $\mathrm{B}$ & $\mathrm{B}$ & $\mathrm{B}$ \\
\hline 1.5 .14 & Data sources mentioned & $\mathrm{B}$ & $\mathrm{A}$ & $\mathrm{B}$ & $\mathrm{B}$ & 4.2 .2$. & Statement as an integrated whole & $\bar{C}$ & $\mathrm{~B}$ & $\mathrm{~B}$ & $\mathrm{C}$ \\
\hline \multirow[t]{2}{*}{1.5 .15} & Methods for wetland functions & $\mathrm{B}$ & $\mathrm{F}$ & $\mathrm{D}$ & $\mathrm{F}$ & 4.3 .1 & Significant adverse \& beneficial impacts & $\mathrm{C}$ & $\mathrm{B}$ & $\mathrm{B}$ & $\mathrm{B}$ \\
\hline & & & & & & 4.3 .2 & Statement must be unbiased & B & $\mathrm{B}$ & $\mathrm{B}$ & $\mathrm{B}$ \\
\hline
\end{tabular}

*The criteria listed in the table were summarised for brevity. Please contact the corresponding author for the complete package 
in all phases and identification of all possible impacts was just satisfactory in only one report (Braamhoek) and poorly or not attempted in the other 3 reports. Details of methods used for prediction and evaluation are not provided in all reports, nor are criteria to predict impact magnitude, which are required to be expressed in measurable quantities with ranges or confidence limits as appropriate.

Impacts from non-standard operating conditions and impacts as a deviation from the base line are poorly considered in one report.

Review Area 3 - Alternatives and mitigation of impacts As shown in Table 2, 3 of the 4 reports were satisfactory in this review area and one just satisfactory. No categories in this review area received an unsatisfactory grade, and one $\mathrm{E}$ and one F score recorded for Sub-Categories 3.1.1 and 3.1.3 (Table 3) are the only unsatisfactory scores of the review area.

The Consideration of alternatives (Category 3.1 ) and the Scope and effectiveness of mitigation measures (Category 3.2) were both rated as satisfactory in all of the reports.

Mitigation measures were generally well done, in contrast to practice observed elsewhere (Sandham and Pretorius, 2007), with the majority of sub-categories well done (A and $\mathrm{B}$ ).

\section{Review Area 4 - Communication of results}

This was the best-performed review area, with $1 \mathrm{~A}$ and $3 \mathrm{Bs}$, and with a single $\mathrm{D}$ score at category and sub-category level, the review area with the highest frequency of satisfactory scores.

The Layout of the report (Category 4.1) received only a single D grade (Braamhoek), but also an A grade, and the Presentation (Category 4.2) received only satisfactory grades. For Emphasis (Category 4.3), i.e. there should be no evidence of lobbying for a certain point of view other than for the environment; all the reports received satisfactory grades (4 Bs)

\section{Conclusions and recommendations}

The review category grades in each review area allowed for strengths and weaknesses to be determined by regarding categories and sub-categories containing only $\mathrm{A}$ and $\mathrm{B}$ grades as strengths and those with only $\mathrm{E}$ and $\mathrm{F}$ grades as weaknesses.

The only two categories that obtained only A and B grades, (1.4 and 4.2) and the other four that could be regarded as well performed were Environmental description (Category 1.4) (Best performed), Presentation of information (Category 4.2) - 4 Bs, Description of the development (1.1), Description of the baseline conditions (1.5), Emphasis and lack of bias (4.3) and Layout (4.1). The last category is somewhat anomalous since it is 1 of only 3 categories that scored an A even though 1 report was graded just unsatisfactory.

There were no categories with only $\mathrm{E}$ and $\mathrm{F}$ grades, but the categories with poorest performances were Identification of impacts (Category 2.2) (Worst performed), Wastes (1.3), Site description (1.2), Assessment of impact significance (2.5), Definition of potential impacts (2.1), Scoping (2.2) and Prediction of impact magnitude (2.4).

It is evident from the distribution of $\mathrm{A}$ and $\mathrm{B}$ scores that there are some areas of strength, mainly in Review Areas 1 and 4. The distribution of $\mathrm{E}$ and $\mathrm{F}$ scores reveals no significant weakness at category level, although at sub-category level a few areas of weaker performance are revealed. Somewhat anomalous here is the relatively poor performance of the site description and wastes. In other studies these tend to be better performed along with the rest of the Review Area 1 categories and sub-categories.

The rest of the rankings are in general accord with findings elsewhere (Lee, 2000; European Commission, 1996; Sandham and Pretorius, 2007)

The key findings on the quality of the EIRs for projects with the potential to affect wetlands are:

- All of the EIRs reviewed were found to be of satisfactory quality

- Generally, the descriptive and presentational parts of the reports received higher scores than the more analytical components of the EIRs

- Environmental description and particularly biological components were very well performed

- The areas of greatest weakness related to impact identification, magnitude and significance of impacts, site description and wastes

- Issues specific to wetlands such as the national wetland policy, and consultation of the national wetland site inventory were poorly addressed, but since these had not yet been developed in South Africa, they were regarded as not applicable

- A significant amount of variation in scores was observed amongst different reports, where overall scores are the same, but with variation at lower tiers, e.g. the EIR for MooiMgeni had the most $\mathrm{E}$ and $\mathrm{F}$ category scores, but also most $\mathrm{A}$ scores, whereas apart from one D each, Braamhoek and Seekoeivlei had only Bs and Cs, but no As, yet all three of these EIRs received a $\mathrm{B}$ for overall report quality. This apparent anomaly is discussed below.

These findings seem to indicate that in terms of the quality of EIRs, EIA practice in South Africa has closely paralleled that elsewhere in the world. There appears to be sufficient skill in environmental description and communication of findings, but assessment of impact significance is inadequate. Assessment of impact magnitude and significance needs to be improved, and the absence of detailed review guidance is a constraint, since environmental assessment practitioners have little idea of what is required for best practice EIRs.

\section{Addressing potential limitations}

In the application of the review package, certain potential limitations in the utility of the review package became evident, and need to be addressed.

- The weighting of criteria. This limitation is partially disguised by the fact that variation in scores at lower levels tends to be 'smoothed out' at higher levels in the review hierarchy. This allows for the apparent anomaly that reports with a wide variation in quality between various criteria could achieve the same overall score. The manner in which weighting of criteria can address this anomaly is illustrated by comparing two criteria, for example the number of visitors entering the site and the significance of an impact. Clearly, a high score in estimating the number of visitors should make a lesser contribution to overall report quality than a high score in estimation of significance. Currently, weighting is addressed by qualitative (A to F) scoring.

- The need for maximal objectivity in obtaining review scores. This is best addressed by using at least 2 reviewers as required by the guidelines for application of the review package, thereby increasing the internal validity of the scores and improving the robustness of the review package. 
- There is a need for review packages to be sector-specific. The general methodology is sufficiently generic for wide application, but the criteria at category and sub-category level must be adapted according to the needs of the sector.

\section{The way forward}

The successful implementation of the EIA-process depends in part on the production of high-quality reports. Hence, it is suggested that:

- The use of a quality review checklist by EIA practitioners and authorities as an additional tool to the EIA regulations (South Africa, 2006) and the integrated environmental management series (DEAT, 2002) can further improve the quality of the reports for projects with the potential of affecting wetlands.

- The use by EIA practitioners of a wetland review checklist will assist in ensuring that all key aspects are addressed before submission to the relevant authority, i.e. the report is scientifically and technically sound; the report is clearly and coherently organised and presented so that it can be understood and that it has addressed all the important issues to make a decision about the proposed development. This will further assist in fast-tracking the approval process usually delayed by the request for additional information from the applicant as a result of inadequate reports.

- Regular use of the review checklist by EIA practitioners and authorities for ascertaining the quality of the environmental impact reports will contribute to a base line of EIR quality for evaluation of wetlands EIA practice under the new 2006 regulations.

It is concluded that the 4 reports were rated as satisfactory despite some omissions and/or inadequacies observed, indicating that EIA practice with regard to wetlands-affecting projects is generally in line with international best practice. There is a need for improved guidance on EIR best practice for projects that have the potential to adversely affect wetlands. A significant research need exists regarding the review package, EIR quality and EIA effectiveness in this type of development and must be addressed as a matter of national importance to ensure sustainability of the fragile South African wetland resource.

\section{Acknowledgements}

The assistance of the following is gratefully acknowledged: Department of Environmental Affairs and Tourism for allowing access to EIA files, and two anonymous referees for their valuable comments.

\section{References}

BARBIER EB, ACREMAN MC and KNOWLER D (1996) Economic Valuation of Wetlands: A Guide for Policy Makers and Planners. Ramsar Convention Bureau, Gland, Switzerland. 138 pp.

BARDECKI (1984) Effective wetlands conservation efforts require careful reasoning and strong incentives to landowners. J. Soil Water Conserv. 39 166-169.

BARKER A and WOOD C (1999) An evaluation of EIA system performance in eight EU countries. Environ. Impact Assess. Rev. 19 387-404.

CANADIAN ENVIRONMENTAL ASSESSMENT AGENCY (1996) A Guide on Biodiversity and Environmental Assessment. Biodi- versity Convention Office, Minister of Supply and Services Canada, Quebec: http://www.ceaa-acee.gc.ca/012/newguidance e.htm (Accessed on 18/02/08).

DEPARTMENT OF ENVIRONMENTAL AFFAIRS and TOURISM (DEAT) (1998) Guideline Document: EIA Regulations, Implementation of Sections 21, 22 and 26 of the Environment Conservation Act, DEAT, Pretoria, South Africa. 48 pp.

DEPARTMENT OF ENVIRONMENTAL AFFAIRS and TOURISM (DEAT) (1999) State of the Environment in South Africa - An Overview. DEAT, Pretoria, South Africa. 17 pp.

DEPARTMENT OF ENVIRONMENTAL AFFAIRS and TOURISM (DEAT) (2002) Integrated Environmental Management Series, Information Series 1-6. DEAT, Pretoria, South Africa.

DUGAN P (1994) Wetland Conservation - A Review of Current Issues and Required Action. IUCN, Gland, Switzerland. 96 pp.

EISENHARDT K (2002) Building theories from case study research. In: Huberman A and Miles M (eds.) The Qualitative Researcher's Companion. Sage Publications, London. 5-36.

ELKIN TJ and SMITH PGR (1988) What is a good environmental impact statement? Reviewing screening reports from Canada's national parks. J. Environ. Manage. 26 71-89.

EUROPEAN COMMISSION (1996) Evaluation of the Performance of the EIA Process. Wood C, Barker A, Jones CE, Hughes J (authors) Vol. 1: Main Report. European Commission, Brussels; http://ec.europa.eu/environment/eia/eia-support.htm (Accessed on 18/02/08).

FURTER L (2003) Floods, storm water management and wetlands. IEMSA 28 (3) 17-18.

GERAGTHY PJ (1996) Environmental impact assessment practice in Ireland following the adoption of the European directive. Environ. Impact Assess. Rev. 16 (3) 189-211.

GLASSON J, THERIVEL R and CHADWICK A (1995) Introduction to Environmental Impact Assessment. Principles and Procedures, Process, Practise and Prospects. UCL Press, London, UK. 141-165.

HICKIE D and WADE M (1998) Development of guidelines for improving the effectiveness of environmental assessment. Environ. Impact Assess. Rev. 18 (3) 267-287.

IBRAHIM A (1992) An Analysis of Quality Control in the Malaysian Environmental Impact Assessment Process. M.Sc. dissertation, Department of Planning and Landscape, University of Manchester, Manchester, UK.

KOTZE DC (2000) Wetlands and Water Quality (Paper compiled for the Mondi Wetlands Project), www.wetland.org.za/wetpeople.htm (Accessed on 17/11/04).

LEE N and BROWN D (1992) Quality control in environmental assessment. Proj. Appraisal 7 (1) 41-45.

LEE N AND COLLEY R (1992) Review of the Quality of Environmental Statements. Occasional Paper No. 24 ( $2^{\text {nd }}$ edn.). EIA Centre, Department of Planning and Landscape, University of Manchester, Manchester, UK.

LEE N, COLLEY R, BONDE J and SIMPSON J (1999) Reviewing the Quality of Statements and Environmental Appraisals. Occasional Paper No. 55. EIA Centre, Department of Planning and Landscape, University of Manchester, Manchester, UK.

LEE N and DANCEY R (1993) The quality of environmental impact statements in Ireland and the United Kingdom: A comparative analysis. Proj. Appraisal 8 (1) 31-36.

LEE N (2000) Reviewing the quality of environmental assessments (Chapter 8). In: N Lee and C George (eds.) Environmental Assessment in Developing and Transitional Countries. John Wiley \& Sons, Ltd., Chichester, UK. 137-147.

LEU WS, WILLIAMS WP and BARK AW (1996) Development of an environmental impact assessment evaluation model and its application. Environ. Impact Assess. Rev. 16 (2) 115-133.

MWALYOSI R and HUGHES R (1998) The Performance of EIA in Tanzania: An Assessment. International Institute for Environment and Development, London, UK.

ODUM P (1983) Wetlands and Values. J. Soil Water Conserv. 38380.

RAMSAR CONVENTION (1994) Convention on Wetlands of International Importance especially as Waterfowl Habitat. The Convention on Wetlands text, as amended in 1982 and 1987. http://www.ramsar. org/key conv e.htm (Accessed on 18/02/08). 
RAMSAR CONVENTION SECRETARIAT (2007) Impact assessment: Guidelines for incorporating biodiversity-related issues into environmental impact assessment legislation and/or processes and in strategic environmental assessment. Ramsar Handbooks for the Wise Use of Wetlands ( $3^{\text {rd }}$ edn.) Vol. 13. Ramsar Convention Secretariat, Gland, Switzerland.

ROBSON C (2002) Real World Research (2 ${ }^{\text {nd }}$ edn.). Blackwell, Oxford, UK.

ROUT D (1994) An Analysis of the EIA Process and EIA Reports produced for Selected Industrial Developments in the State of Orissa in India. M.Sc. dissertation, Department of Planning and Landscape, University of Manchester, Manchester, UK.

ROSS WA (1987) Evaluating environmental impact statements. J. Environ. Manage. 25 137-147.

SADLER B (1996) Environmental Assessment in a Changing World: Evaluating Practice to Improve Performance. Final report of the International Study of the Effectiveness of Environmental Assessment. www.ea.gov.au/assessments/eianet/eastudy/final/chapter2. html (Accessed on 30/06/03).

SANDHAM LA and PRETORIUS HM (2007) A review of EIA report quality in the North West Province of South Africa. Environ. Impact Assess. Rev. 28 (4-5) 229-240. DOI:10.1016/j.eiar.2007.07.002.

SILVIUS MJ, ONEKA M and VERHAGEN A (2000) Wetlands: Lifeline for people on the edge. Phys. Chem. Earth 25 (7- 8) 645-652.

SIMPSON J (2001) Developing a review package to assess the quality of EA reports of local authority structure and local plans in the UK. Environ. Impact Assess. Rev. 21 (1) 83-95.

SOUTH AFRICA (1989) The Environment Conservation Act, Act No. 73 of 1989. Pretoria, Government Printer, South Africa.

SOUTH AFRICA (1997) Regulations under the Environment Conservation Act, Act No. 73 of 1989 - GN 1182, 1183, 1184, Government
Gazette 18261:387, 5 September. Pretoria, Government Printer, South Africa.

SOUTH AFRICA (1998) The National Environmental Management Act, Act No. 107 of 1998. Pretoria, Government Printer, South Africa.

SOUTH AFRICA (2006) Regulations under the National Environmental Management Act, Act 107of 1998 - GN R385, GN R386 and GN R387 of 21 April 2006. Pretoria, Government Printer, South Africa.

SOWMAN L, FUGGLE R and PRESTON G (1995) A review of the evolution of environmental evaluation procedures in South Africa. Environ. Impact Assess. Rev. 15 (1) 45-67.

THE WORLD BANK (1997) Biodiversity and Environmental Assessment. Environmental Assessment Source Book Update No. 20: http://go.worldbank.org/541FG6IVA0 (Accessed on 18/02/08).

THE WORLD BANK (2002) Wetlands and Environmental Assessment. Environmental Assessment Source Book Update No. 28: http:// go.worldbank.org/541FG6IVA0 (Accessed on 18/02/08).

WALMSLEY RD (1988) A Description of the Wetlands Research Programme. South African National Scientific Programmes Report (145) 1- 26. Council for Scientific and Industrial Research, Pretoria.

WESTON J (2000) Reviewing environmental statements: New demands for the UK's EIA procedures. Planning, Practice and Res. 15 Issue $1 / 2$.

WOOD C (1988) EIA in the plan making. In: Wathern P (ed.) Environmental Impact Assessment: Theory and Practice. Unwin Hyman, London, UK. 161-196.

WOOD C (2003) Environmental Impact Assessment: A Comparative Review (2 $2^{\text {nd }}$ edn.). Pearson, Harlow, England.

YIN R (2003) Case Study Research: Design and Methods (3 ${ }^{\text {rd }}$ edn.) Applied Social Research Methods Series - Volume 5. Sage Publications, London, UK. 